TITLE:

\title{
A NEW SPECIES OF PRIMOVULA FROM JAPAN, PARASITIC TO A GORGONID (GASTROPODA : OVULIDAE)
}

AUTHOR(S):

Yamamoto, Torao

\section{CITATION:}

Yamamoto, Torao. A NEW SPECIES OF PRIMOVULA FROM JAPAN, PARASITIC TO A GORGONID (GASTROPODA : OVULIDAE). PUBLICATIONS OF THE SETO MARINE BIOLOGICAL LABORATORY 1971, 19(4): 191-195

ISSUE DATE:

1971-12-27

URL:

http://hdl.handle.net/2433/175724

RIGHT: 


\title{
A NEW SPECIES OF PRIMO VULA FROM JAPAN, PARASITIC TO A GORGONID (GASTROPODA: OVULIDAE) ${ }^{1)}$
}

\author{
TORAO YAMAMOTO \\ Rinkai, Sirahama, Wakayama Prefecture, Japan
}

With Plate VIII and 2 Text-figures

In 1951, I obtained an empty shell of Primovula near the tip of Cape Bansyosaki in Sirahama and asked Dr. T. Kuroda for identification. As the morphology of the shell resembles very closely that of Primovula (Primovula) renovata (IREDALE), though the shell colour differs somewhat, it has been regarded since as a variety of this species. However, in a long time of observations on live specimens of many different species of Primovula, I have had some chances to examine repeatedly the live specimens of both Primovula renovata and so-called its variety and found that the colour pattern of the mantle is definitely different between the two. There has been no intermediate between them. Closer examinations have revealed some constant, though rather exact, differences in the morphology of their shell, too. Therefore, they can never be placed under the single and same species. So far, this shell in question has not yet been identified with any species described in "The living species of Amphiperatinae" (SGHILDER, 1932) and in some other papers which were published after it and including descriptions of some Primovula. Thus, I have come to the conclusion that the shell in question is better described as a new species.

My sincere gratitude is due to Dr. T. Kuroda who has been my teacher in conchology for a long time and also to Messrs. Kentaro Sasaki, Kinya Mase, Yorisaburo Toki, Yasuo Koyama and Tadasi TANaka for valuable specimens and information, to Dr. Katura Oyama and Dr. Sadao Kosuge for suggestions and references. Every step during the series of observations of living Primovula has reminded me of my late daughter Yukiyo who supported the work in many ways. The present paper is dedicated to her memory.

\section{Primovula (Primovula) tigris n. sp.}

(Japanese name: Torahu-kebori-takaragai)

Types: Holotype. $14.9 \mathrm{~mm}$ long, $7.5 \mathrm{~mm}$ broad and $6.2 \mathrm{~mm}$ high; collected by

1) Contributions from the Seto Marine Biological Laboratory, No. 522.

Publ. Seto Mar. Biol. Lab., XIX (4), 191-195, 1971

(Article 13) 
ҮАмамото on March 31, 1961, from a gorgonid octocoral Euplexaura, $17 \mathrm{~m}$ deep off Yuzaki, Sirahama, Wakayama Prefecture.

Paratypes. No. 1, $13.2 \mathrm{~mm}$ long, $6.2 \mathrm{~mm}$ broad and $6.0 \mathrm{~mm}$ high; collected by Үамамото on Dec. 19, 1957, $10 \mathrm{~m}$ deep off Yuzaki. No. 2, $12.2 \mathrm{~mm}$ long, $6.0 \mathrm{~mm}$ broad and $4.7 \mathrm{~mm}$ high; collected by K. SAsaki on July 21, 1963 at Cape Bansyosaki, Sirahama. No. 3, $13.6 \mathrm{~mm}$ long, $6.2 \mathrm{~mm}$ broad and $5.7 \mathrm{~mm}$ high; collected by K. MAse in April, 1971 at Maguti, Miura Peninsula, Kanagawa Prefecture.

Shell: The shell is cylindrically fusiform and thick. The outer lip is flattened, thickened, declivous towards the aperture, and curved rather abruptly in the anterior one-fourth and somewhat gently in the posterior one-third, while the middle range between these curves is nearly straight. The denticulation of the outer lip is some-
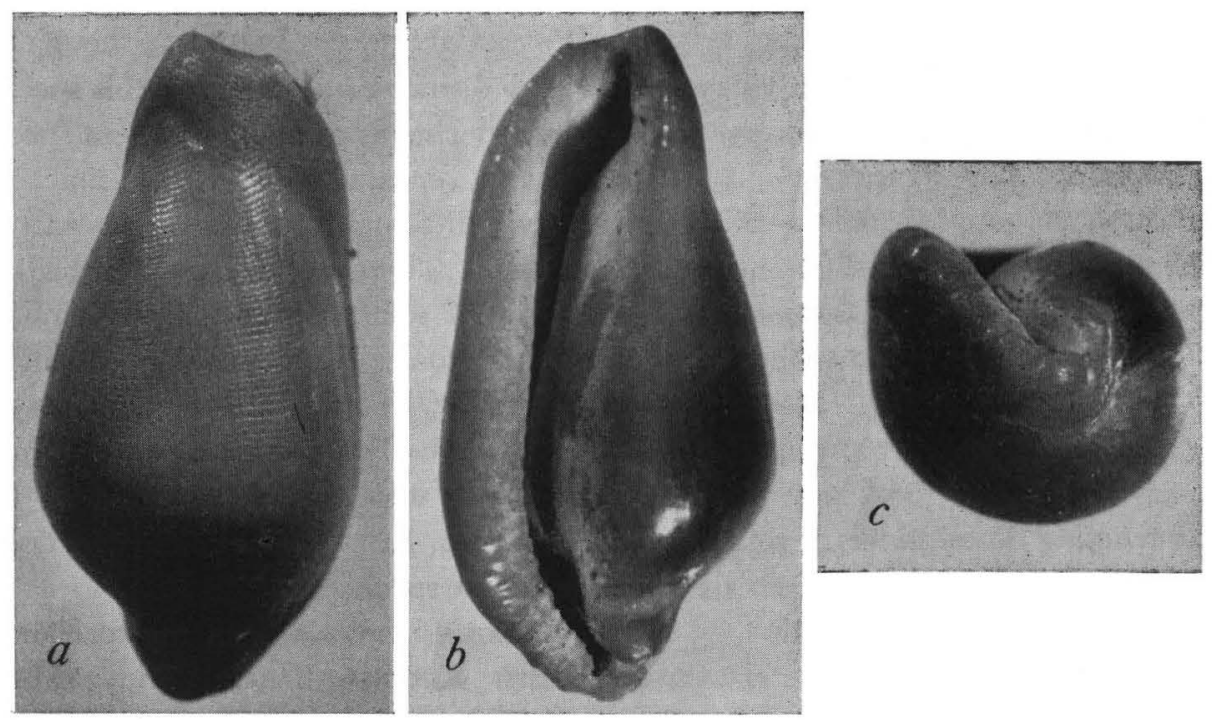

Fig. 1. Primovula (Primovula) tigris n. sp., holotype. a-dorsal side, b-ventral side, c- posterior side.

what irregular and indistinct in the anterior half, though there are 15-16 teeth, attaining the adaxial edge of the lip, in the posterior half from about the middle to the posterior end.

The base is inflated, elongate ovate, and narrowing abruptly posteriorly and gradually anteriorly; extremely faint striae on the surface. The columella is carinate, widened about the anterior one-fourth rather abruptly and then gradually posteriorly to the posterior one-third where it is widest. Thus, the aperture is narrow in the posterior part, least in the breadth at the posterior one-third, then widened gradually anteriorly to the anterior one-fourth where it is enlarged abruptly. The edge of the anterior outlet is never acute, but rather truncate obliquely. The first funiculum is distinct, but insignificant, with two extremely faint crenulations on it. The second 
funiculum is defined but very indistinctly. The first posterior outlet is well marked, but the second is much less remarkable. The fossula is very short.

The dorsum is inflated and with the rounded carina; about 120 fine transverse striae over the surface, except for the wide peripheral callus along the outer lip.

The dorsal side is wholly orange yellow (Pl. VIII, figs. 1, 3), especially darker in the peripheral callus along the outer lip. The base is orange brown, with the callus and the outer lip paler, especially the former becomes whitish towards the columellar edge.

Animal body: The animal will extend to $20 \mathrm{~mm}$ in length and is yellow orange as a whole, marked with a number of black stripes bordered with thin white margin. The tentacle is white in the distal one-third, black in the middle one-third, and then yellow proximally with a white ring just basally to the drak median band. The cylindrical siphon is yellowish orange. Eyes are black and each encircled by a light yellow ring.

The mantle is light yellowish orange and furnished principally with about 20 stripes which are black, running transversely and spaced rather regularly and each hemmed round by thin white margin; in addition there are a few small elliptical black patches.

The dorsal surface of the tail is sprinkled subconfusedly with black oval spots, somewhat irregular in size. There are more than 20 black spots on the dorsal side of the anterior part of the foot (or the basal portion of the mantle), these are a little smaller than those on the tail. The sole is paler and without any dark spots.

Habitat and distribution: Inhabiting limitedly on a gorgonid, Euplexaura erecta Kükenthal (thanks to Prof. Utinomi for identification), in 10 to $20 \mathrm{~m}$ deep and feeding on polyps of the host. So far, probably about 20 shells have been collected

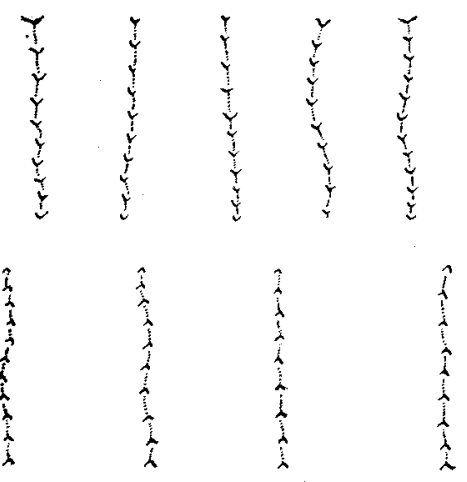

Fig. 2. Striae over the dorsal surface of the shell in Primovula (Primovula) tigris n. sp. (above) and Primovula (Primovula) renovata (IREDALE) (below), under the same magnification, $\times 73$.

by different collectors from Sirahama, Nada (by Mr. Toki), Minabe (by Mr. SAsaki), and Cape Sionomisaki, Wakayama Prefecture and from Maguti (by Mr. MASE), Kanagawa Prefecture. 
Size: The maximal size known so far is $16.5 \mathrm{~mm}$ long, $8.0 \mathrm{~mm}$ broad and $6.8 \mathrm{~mm}$ high, measured on a specimen collected by Mr. K. SASAKI at Sakai, Minabe near Sirahama and in his possession.

Remarks: As mentioned previously in the introductory note, the present new species resembles most closely Primovula (Primovula) renovata (IREDALE) which is also living on the same species of gorgonid. There are, however, noticed the following differences between the two species.

(1) The dorsal carina of the shell of $P$. renovata is more prominent and angular, and definable by a whitish or paler band against the purplish fulvous ground colour (Pl. VIII, fig. 4) which is the commonest colouration throughout the specimens found in Japan. The white band may be faint in some shell. However, such a zone is never seen in the present new species.

(2) The first funiculum in $P$. renovata is well developed, projecting out, and furnished with $4-5$ distinct crenulations. The second funiculum is also much produced. Then, the first posterior outlet is excavated in $P$, renovata, though the second posterior outlet is not distinct, either.

(3) The anterior part of the outer lip is curved more strongly in the present new species than in $P$. renovata.

(4) There are much fewer, only 60-70 striae on the dorsal side of the shell in $P$. renovata (Text-fig. 2).

(5) The colour pattern of the mantle in P. renovata (Pl. VIII, fig. 4) differs quite from that of the present new species. When the mantle covers the shell wholly, the pattern consists of seven rows of black spots, 4 to 7 spots in a row. The tail is furnished with a brownish feather-like pattern, with the axis of the feather in the axis of the tail. The tentacle is coloured in P. renovata purplish except for the tip and base.

(6) Primovula rhodia (A. Adams), P. formosa (Adams et Reeve) and $P$. frumentum (SowErby), all somewhat allied to the present new species, are provided each with the mantle of a quite different colour and pattern. The first two are punctated rather densely with blackish (rhodia) or darker (formosa) spots over the mantle, while the last is so sparsely with larger darker spots over the cream yellow mantle.

The colour pattern of the present new species thus contrasts very clearly with those of a punctated type of all allied species. The specific name, tigris, of the new species is derived from its unique colour pattern which reminds us of the tiger fur.

\section{REFERENCES}

Azuma, M. and C. N. CAte. 1971. Sixteen new species and one genus of Japanese Ovulidae. Veliger, 13 (3), 261-268, figs. 1-24.

Cate, C. N. 1964. A new species of Primovula from the Philippines. Veliger, 11 (2), 102-103, pl. 19.

1969. A revision of eastern Pacific Ovulidae. Veliger, 12 (1), 95-102, Pls. 7-10.

1970. A new species of Japanese Ovulidae. Veliger, 13 (2), 181, fig. 1. 
Cernohorsky, W. O. 1967. The Ovulidae, Pediculariidae and Triviidae of Fiji. Veliger, 10 (4), 353-374.

Kuroda, T. 1958. The Japanese species of Primovula series of the Amphiperatidae (Gastropoda). Venus, 20 (2), 167-173. (in Japanese)

Mase, K. 1969. Amphiperatidae of Miura Peninsula. Tiribotan, 5 (8), 219-221, PIs. 8-9. (in Japanese)

Schilder, F. A. 1932. The living species of Amphiperatinae. Proc. Malac. Soc. London, 20, 4664, Pls. 3-5.

Yамамото, T. 1961. Ecology of Primovula epibiotic on Octocorallia. Venus, 21 (2), 227-228. (in Japanese)

1963. Memoranda on animals and plants from Tanabe Bay, II. Tanabe-Bunkazai, 7, 8092. (in Japanese) 


\section{EXPLANATION OF PLATE VIII}

1-3 Primovula (Primovula) tigris n. sp. (Photo by Mr. T. TANaka)

1. Live animal, Paratype No. 2, dorsal side.

2. The same, posterior side.

3. The same, right side.

4. Primovula (Primovula) renovata (IREDALE)

A live animal extended to $12 \mathrm{~mm}$ in length, dorsal side. Collected by Mr. K. Sasaki on September 8, 1963 at Oguso, Cape Bansyosaki, Sirahama. 
Publ. Seto Mar. Biol. Lab., XIX (4), 1971.

PLATE VIII
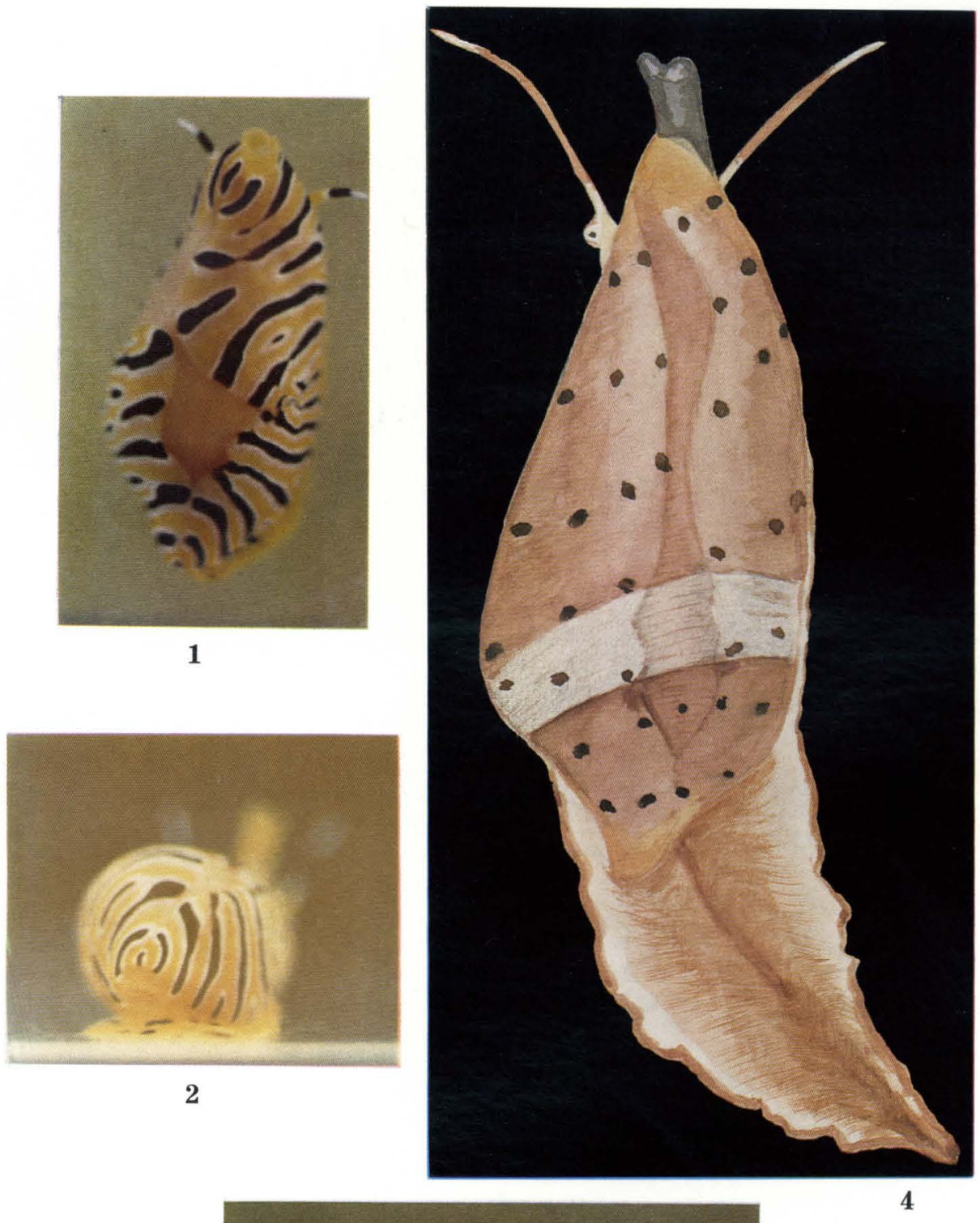

3

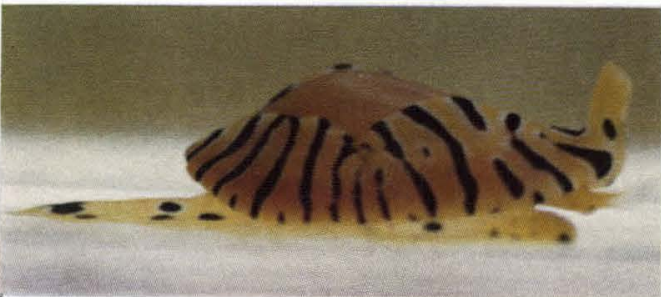

T. Yамамото: A New Primovula from Japan 